\title{
International Unit per Second
}

National Cancer Institute

\section{Source}

National Cancer Institute. International Unit per Second. NCI Thesaurus. Code C85648.

International units per second. 